Indonesian Journal of Biotechnology, December, 2013

Vol. 18, No. 2, pp.144-150

\title{
A Study on Production of Poly- $\beta$-Hydroxybutyrate Bioplastic from Sago Starch by Indigenous Amylolytic Bacteria
}

\author{
Nur Arfa Yanti ${ }^{1 *}$, Langkah Sembiring ${ }^{2}$, Sebastian Margino ${ }^{3}$ and \\ Nurhayani. H. Muhiddin ${ }^{1}$
}

\begin{abstract}
${ }^{1}$ Department of Biology, Faculty of Mathematics and Natural Science, Universitas Halu Oleo, Kendari ${ }^{2}$ Microbiology Laboratory, Faculty of Biology, Universitas Gadjah Mada, Yogyakarta

${ }^{3}$ Faculty of Agriculture, Universitas Gadjah Mada, Yogyakarta
\end{abstract}

\begin{abstract}
Bacillus sp. PSA10 and Bacillus sp. PPK5 were two indigenous strain amylolytic bacteria from Southeast Sulawesi that have ability to produce bioplastic poly- $\beta$-hydroxybutyrate (PHB) from sago starch. The study was attempted to determine the mechanism of PHB production by bacteria amylolytic was grown on sago starchcontaining media. Two amylolytic bacteria i.e. Bacillus sp. PSA10 and Bacillus sp. PPK5 was grown for $168 \mathrm{~h}$ in a mineral salts medium with sago starch as carbon source. Growth of amylolytic bacteria was monitored by cell dry weight. Extraction of PHB was done by N-hexane acetone-diethyl ether method and PHB content was quantified with UV spectrophotometer at $235 \mathrm{~nm}$. Glucose level was determined by using kit of glucose GOD 10" and was quantified with spectrophotometer at $500 \mathrm{~nm}$. Sago starch concentration was determined by phenol method using specthrophotometer at $490 \mathrm{~nm}$. The result of the study showed that Bacillus sp. PSA10 was produced PHB up to 66,81 \% (g PHB/g cell dry weight) at $48 \mathrm{~h}$ and Bacillus sp. PPK5 up to 24,83 $\%$ (g PHB/g cell dry weight) at $84 \mathrm{~h}$. Bacillus sp. PSA10 has ability to converse sago starch to be PHB directly without glucose accumulation in the media, whereas Bacillus sp. PPK5 have to accumulate glucose as product of sago starch hydrolysis to produce of PHB. PHB synthesis by Bacillus sp. PHB production on sago starch of the Bacillus sp. PSA10 was found to be growth-associated whereas Bacillus sp. PPK5 was found to be non growth-associated. Therefore, two indigenous amylolytic bacteria were having of difference in biosynthesis mechanism of PHB in sago starch medium and their characteristics of PHB synthesis should be considered in developing cultivation methods for the efficient production of PHB.
\end{abstract}

Keywords : Production, PHB, Amylolytic bacteria, Sago starch.

\section{Introduction}

Poly- $\beta$-hydroxybutyrate $(\mathrm{PHB})$ is a synthesized by a wide variety of bacteria as intracellular and energi storage materials. These biopolymer is a biodegradable and biocompatible thermoplastic, so that it is an effective substitute for petrochemical plastics in applications in which both thermoplasticity and biodegradability are required (Anderson and Dawes, 1990). However, the higher

\footnotetext{
*Corresponding author:

Nur Arfa Yanti

Microbiological Laboratory, Department of Biology,

Universitas Halu Oleo, Kendari.

E-mail: arfayanti73@yahoo.com
}

production cost of PHB compared with that of petrochemical plastics has hampered widespread use of PHB in everyday live. In $\mathrm{PHB}$ production, about $40 \%$ of total production cost is for raw material (Kim, 2000). Thus, the use of cheaper carbon source is required in order to reduce the high production cost of PHB.

Sago starch is one of cheaper candidates for cultivation substrate of PHB production. The utilization of sago starch as cultivation substrate for PHB production hopefully can reduce the production cost of PHB while giving an added value to sago starch. Prior to fermentation, sago starch is hydrolized to glucose by two step, liquefaction and 
saccharification. The utilization of sago starch in PHB production, needs enzymatic hydrolysis for sago starch degradation since many microorganism do not produce these enzymes natively (Syamsu et al., 2006). This suggests there is a need for exploitation of bacterial culture for the co-production of sago starch hydrolyzing enzyme (amylolytic bacteria) as well as PHB.

Bacillus sp. PSA10 and Bacillus sp. PPK5 were amylolytic bacteria isolated from Southeast Sulawesi that can produce PHB in a sago starch medium (Yanti et al., 2009a; Yanti et al., 2009b). Bacillus sp. PPK5 appeared to have a higher amylolytic activity than Bacillus sp. PSA10, i.e. 99,30 DUN/ml and 42,74 DUN/ml, respectively (Yanti et al., 2009b; Yanti et al., 2009c). The utilization of the amylolytic bacteria for synthesis of PHB from sago starch, hopefully is the effort to overcome the problem of utilization of sago starch as substrate PHB production. Hence, study of mechanism of PHB synthesis have been done to be considered in developing cultivation methods for the efficient production of PHB.

The present study attempted to determine the mechanism of $\mathrm{PHB}$ production in sago starch medium by indigenous amylolytic bacteria. PHB might have value as environmentally-degradable thermoplastics for a wide range of agricultural, marine, and medical applications.

\section{Materials and Methods \\ Bacteria and culture condition}

Bacillus sp. PSA10 and Bacillus sp. PPK5 were obtained from sago starch processing area in Konawe regency, Southeast Sulawesi (Yanti et al., 2009a). These strains have been used for the current study. Both strains were maintained in starch nutrient agar slants.

The shake-flask experiments were performed in $500 \mathrm{ml}$ conical flasks using $200 \mathrm{ml}$ of chemically-defined mineral salts medium at an initial pH of 7 (Yanti, et al., $2009 \mathrm{~b})$. The modified medium contained $(\mathrm{g} / \mathrm{l})$ sago starch, 20; $\mathrm{Na}_{2} \mathrm{HPO}_{4} .7 \mathrm{H}_{2} \mathrm{O}$ 6,7; $\mathrm{KH}_{2} \mathrm{PO}_{4^{\prime}}$
1,5; $\left(\mathrm{NH}_{4}\right)_{2} \mathrm{SO}_{4}, 1 ; \mathrm{MgSO}_{4} 7 \mathrm{H}_{2} \mathrm{O}, 0,2 ;$ Ferrous Amonium Citrat, 0,06; $\mathrm{CaCl}_{2} .2 \mathrm{H}_{2} \mathrm{O}, 0,01$ and Trace element solution $1 \mathrm{ml} / \mathrm{L}$ (Ramsay et al., 1990). The inoculum was prepared in test tube containing $5 \mathrm{ml}$ of sterile nutrient broth and then they were incubated at $30^{\circ} \mathrm{C}$ for $24 \mathrm{~h}$ on rotary shaker at $150 \mathrm{rpm}$. The seed cultures, $10 \mathrm{ml}$ were transferred into $190 \mathrm{ml}$ of sterile modified mineral salts medium. Cultivation was carried out for $168 \mathrm{~h}$ at $30^{\circ} \mathrm{C}$

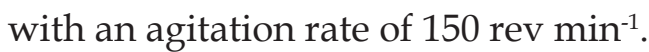

Ten ml of samples were taken aseptically from each flask for the analysis of dry cell weight, PHB content, glucose and sago starch level during the growth. The fermentation broth was centrifuged at $3000 \mathrm{rpm}$ for 20 minutes. The bacterial pellet was collected for analysis of PHB content and dry cell weight and the supernatant kept for analysis glucose and sago starch concentration.

\section{Determination of Cell dry weight}

Biomass content were evaluated by gravimetry. The bacterial pellet was dried to constant weight $\left(90^{\circ} \mathrm{C}\right)$ for 24 hours and weighed. The biomass yield was calculated as the cell dry weight.

\section{PHB Extraction}

The pellet was collected by centrifugation at $3000 \mathrm{rpm}$ for $20 \mathrm{~min}$ and pellet was digested with $30 \%$ sodium hypochlorite solution at $30^{\circ} \mathrm{C}$ for overnight. The residue was collected by centrifugation at $3000 \mathrm{rpm}$ for $20 \mathrm{~min}$ and a series of washing steps using water, acetone and finally diethyl ether was performed (Yanti et al., 2009b). The polymer was added with concentrated $\mathrm{H}_{2} \mathrm{SO}_{4}$ and heated for $10 \mathrm{~min}$ at $100^{\circ} \mathrm{C}$ in a water bath. The resultant crotonic acid was measured spectrophotometrically (Shimadzu UV-6A) at $235 \mathrm{~nm}$ against $\mathrm{H}_{2} \mathrm{SO}_{4}$ as blank.

\section{Analytical Procedures}

A series of samples of the growing culture was taken to determine glucose and sago starch levels in the supernatan fluid after centrifugation. The glucose level was 
determined by spectrophotometer at $\lambda 500$ nm using a kit of glucose GOD 10". Sago starch concentration was determined by the phenol method (Dubois et al., 1956) using Shimadzu UV-Vis 6A spectrophotometer at $\lambda 500 \mathrm{~nm}$.

\section{Results and Discussion}

The use of biological system for the production of $\mathrm{PHB}$ as biodegradable plastic is becoming important as a solution to the problems concerning non-biodegradable plastic waste and the environment. PHB offers a range of thermoplastics varying in toughness and flexibility (Madison and Huisman, 1999).

From previous work, it is known that organisms such as Bacillus strains were able to synthesize PHB as storage material using starch as carbon source (Halami, 2008; Aarthy and Ramana, 2011). For this investigation, Bacillus sp. PSA10 and Bacillus sp. PPK5 strains were chosen as promising candidates from a number bacteria known to accumulate PHB in sago starch medium (Yanti et al., 2009a), to determine their mechanism of PHB production in sago starch medium. Bacillus sp. PSA 10 and Bacillus sp. PPK5 were Gram positive bacteria, rod shaped and spores former (Figure 1).

\section{Production of PHB by Bacillus sp. PSA10 in sago starch media}

In this study, $\mathrm{PHB}$ production of the Bacillus sp. PSA10 from sago starch was shown in the Figure 2. Change in sago starch content of the medium, glucose level in medium, the growth of Bacillus PSA10 and PHB accumulation were measured at selected time intervals (Figure $2 \mathrm{a}$ to $2 \mathrm{~d}$ ).

Based on Figure 2a showed that sago starch was reduced by Bacilllus sp. PSA10. Reduction sago starch content in medium showed that sago starch was hydrolized by Bacillus sp. PSA10 for its growth and $\mathrm{PHB}$ production. Figure $2 \mathrm{~b}$ showed that the glucose was produced by hydrolizing enzyme of Bacillus PSA10, however glucose level in medium was detected less than $0,1 \mathrm{~g} / \mathrm{L}$. That result indicated that glucose in medium was consumed immediately by Bacillus sp. PSA10 for its growth and PHB production. This

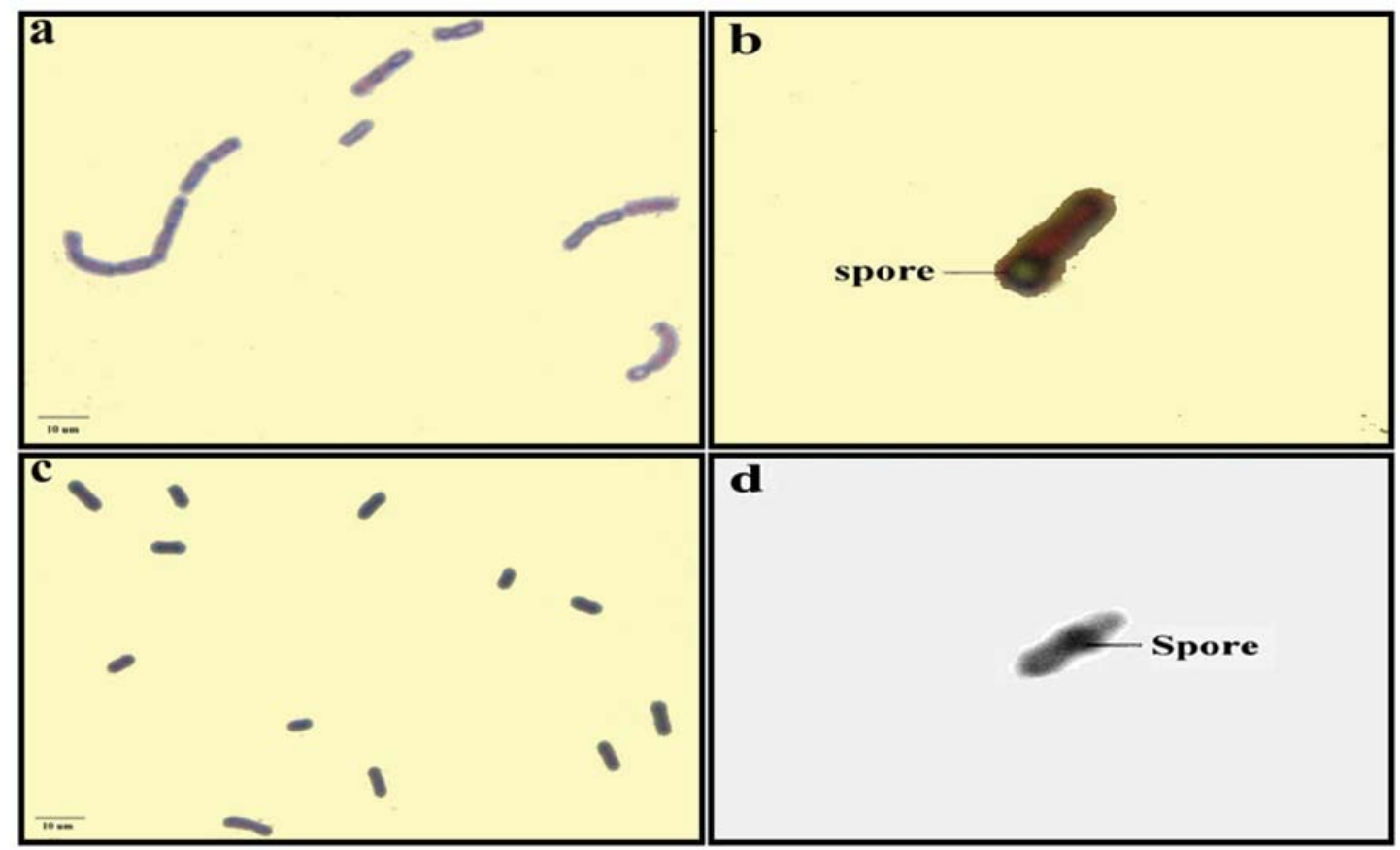

Figure 1. Characteristic features of Bacillus sp. PSA10 and Bacillus sp. PPK5. a-b. Cell shaped and spore formed of Bacillus sp. PSA10. c-d. Cell shaped and spore formed of Bacillus sp. PPK5. 


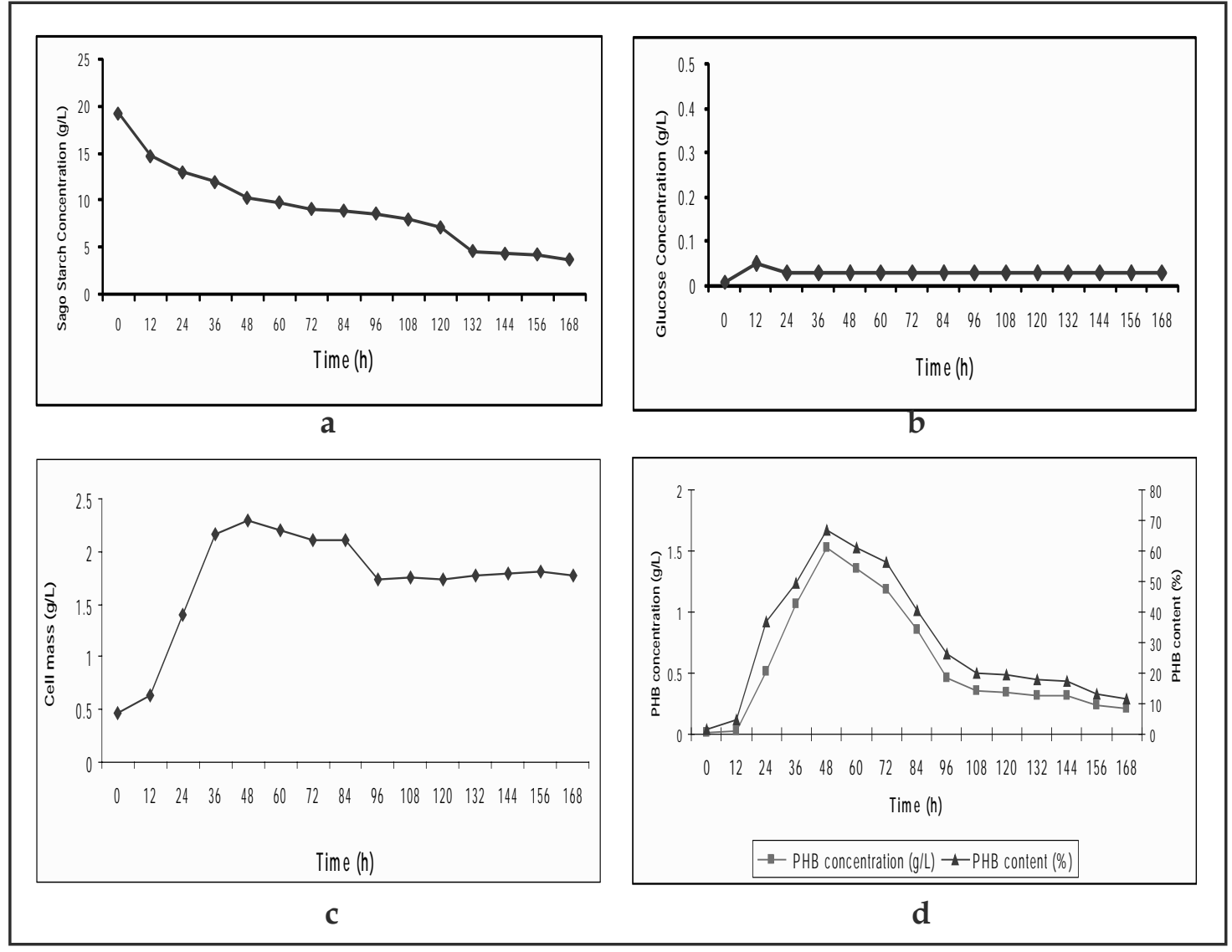

Figure 2. Production of PHB by Bacillus sp. PSA10 was grown in sago starch medium under optimal condition. a. Substrate (sago starch) reduction, b. Glucose level in medium, c. Time course of growth, and $\mathrm{d}$. PHB accumulation

process term simultaneous saccharification and fermentation (SSF). Taherzadeh and Karimi (2007) was reported that in the process $\mathrm{SSF}$, the glucose produced by the hydrolizing enzymes is consumed immediately by the fermenting microorganism present in the culture. SSF process has many advantages to use as fermentation strategy, they are the risk of contamination is low and the number of vessels required is reduced so that resulting in lower capital cost of the process (Taherzadeh and Karimi, 2007). Hence, Bacillus sp. PSA10 most effective utilized for PHB production from sago starch.

Growth of Bacillus sp. PSA10 increased steadily, was reached a maximum at $48 \mathrm{~h}$ and then declined slowly following a stationary phase (Figure 2c). PHB accumulation began from the early exponential phase at $12 \mathrm{~h}$ and continued till the end of this phase (48 h). (Figure 3d). As expected, PHB production was accompanied by simultaneous decrease in sago starch concentration. PHB accumulation of Bacillus sp. PSA10 reached a maximum $(1,53 \mathrm{~g} / 1$ with PHB content $66,81 \%)$ at $48 \mathrm{~h}$ of growth could be explained by the maximum cell growth at that stage. PHB is accumulated during the growth phase (exponential phase). This result indicated that PHB production by Bacillus sp. PSA10 appeared to growthassociated.

The decrease in PHB accumulation observed after the cessation of cell growth at 48 $h$ incubation and after that the concentration cell remained constant (Figure $3 \mathrm{c}$ and Figure $3 \mathrm{~d})$. This result indicated that PHB could be consumed as energy and carbon source by Bacillus sp. PSA10, causing an unsuitable 
condition due to inadequate carbon source in the medium. Yuksekdag et al. (2004), reported that PHB accumulation was decreased after the stationary phase since the bacteria used $\mathrm{PHB}$ as a carbon and nitrogen source.

\section{Production of PHB by Bacillus sp. PPK5 in sago starch media}

PHB production of the Bacillus sp. PPK5 from sago starch was shown in the Figure 3. Change in sago starch content of the medium, glucose level in medium, the growth of Bacillus sp. PPK5 and PHB accumulation were measured at selected time intervals (Figure $3 a$ to $3 d$ ).

Figure $3 \mathrm{a}$ and $3 \mathrm{~b}$ showed that Bacillus sp. PPK5 was hydrolized sago starch to glucose and glucose was accumulated in media. The glucose level in media was increased and reached a maximum level $(4,12$ $\mathrm{g} / \mathrm{L})$ at $24 \mathrm{~h}$ of growth and then decreased (Figure $3 b$ ). This result indicated that the glucose was produced from sago starch by the hydrolizing enzymes of Bacillus sp. PPK5 was not consumed immediately by Bacillus sp. PPK5 for PHB production.

Growth of Bacillus sp. PPK5 increased until $48 \mathrm{~h}$ and then declined slowly following a stationary phase (Figure 3c). PHB accumulation began from the end exponential phase (36 h) and continued until the stationary phase (Figure 3d). PHB production was accompanied by simultaneous decrease in sago starch concentration (Figure 3a) and after glucose accumulation at 24 h of growth (Figure $3 b$ ). The strain of Bacillus sp. PPK5 reached stationary

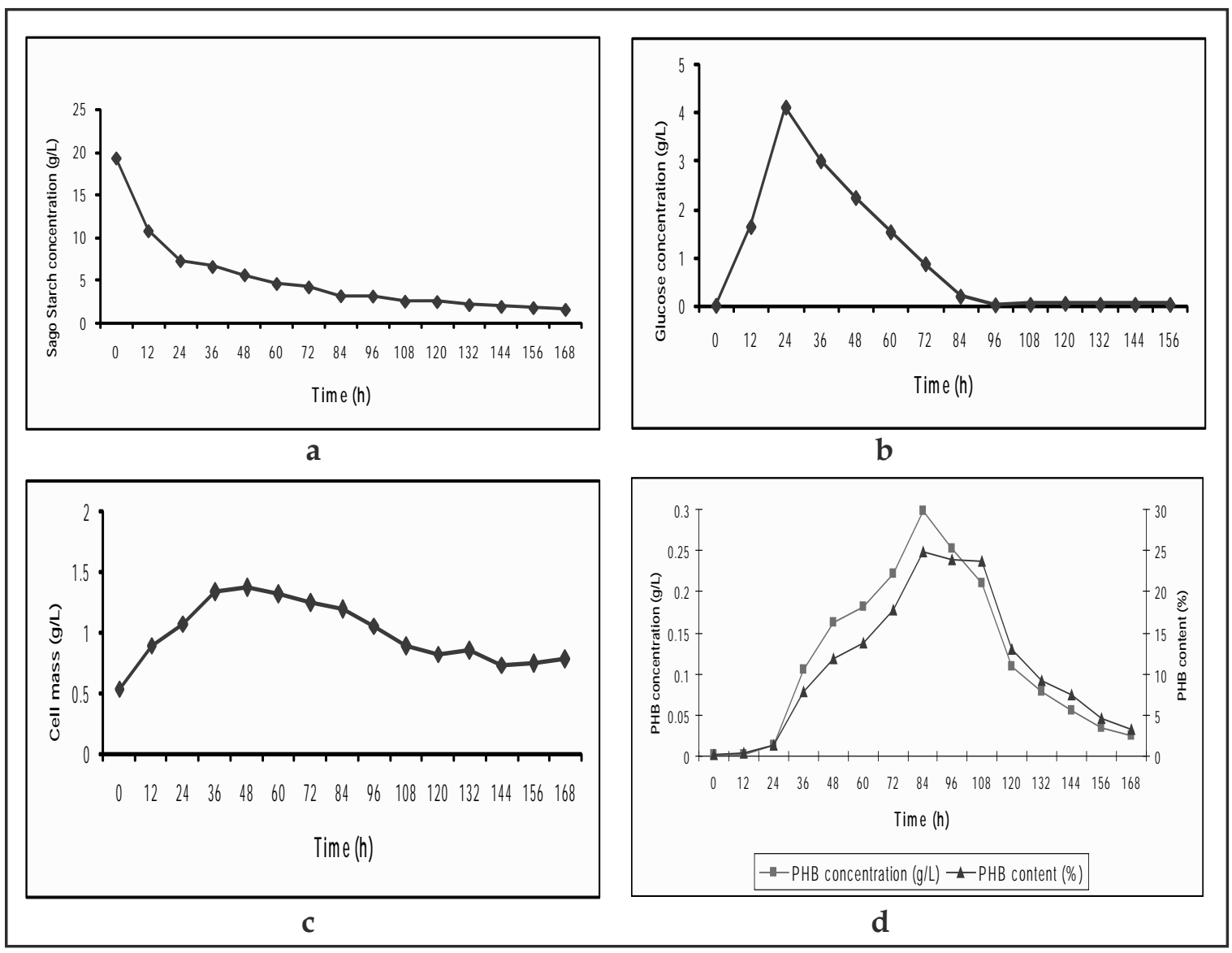

Figure 3. Production of PHB by Bacillus sp. PPK5 was grown in sago starch medium under optimal condition. a. Substrate (sago starch) reduction, b. Glucose level in medium, c. Time course of growth, and d. PHB accumulation 
phase after $48 \mathrm{~h}$ of growth (Figure 3c) and PHB accumulation reached a maximum $(0,298$ g/1 with PHB content 24,83 \%) at the end stationary phase (84 h of growth) (Figure $3 \mathrm{~d}$ ). Accumulating PHB during stationary phase indicated that PHB production by Bacillus sp. PPK5 appeared to non growth-associated. Beside that, PHB production was observed after reduction of glucose. This phenomenon might showed that $\mathrm{PHB}$ production by Bacillus sp. PPK5 requires an excess glucose as the carbon source.

Lee (1996) was reported that bacteria able to synthesize PHB can be divided into two groups based on the culture conditions required for PHB synthesis. The first group, accumulating the polymer during stationary growth phase (non growth-associated), requires limititation of an essential nutrient such as $\mathrm{N}, \mathrm{P}, \mathrm{Mg}, \mathrm{K}, \mathrm{O}$ or $\mathrm{S}$ and an excess of the carbon source for the efficient synthesis of PHB. The most important microorganism for industrial polymer production, Ralstonia eutropha (Lee, 1996), Bacillus subtilis 25 and B. megaterium 12 (Yuksekdag, 2004) belongs to the this group. The second group, accumulating the polymer during the growth (exponential) phase (growth-associated), includes Alcaligenes latus (Lee, 1996), Bacillus mycoides (Thakur et al., 2001) and B. sphaericus NCIM 5149 (Ramadas, et al., 2009). Our strains in this study, Bacillus sp. PSA10 belongs to the second group, since it was accumulate of $\mathrm{PHB}$ during the exponential phase while Bacillus sp. PPK5 belongs to the first group since it was accumulate of PHB during the stationary phase. Therefore, these characteristics should be considered in developing cultivation methods for the efficient production of $\mathrm{PHB}$.

Based on data obtained in the present work, Bacillus sp. PSA10 was capable of PHB accumulation up to $66,81 \%$ of dry cell weight (dcw) at $48 \mathrm{~h}$ incubation and Bacillus sp. PPK5 was capable of PHB accumulation up to $24,83 \% \mathrm{dcw}$ at $84 \mathrm{~h}$ incubation. The bacteria was selected as candidate for industrial PHB production should be easy to grow, accumulated high levels of $\mathrm{PHB}$, short time incubation and capable used an inexpensive the carbon source (Lee, 1996).

The type of PHB synthesis by Bacillus sp. PSA10 was not required excess of glucose (sago starch hydrolized product) as carbon source but Bacillus sp. PPK5 was required excess of glucose for synthesized of $\mathrm{PHB}$, so that incubation time for PHB production of Bacillus sp. PSA10 was to be shorter than Bacillus sp. PPK5. Therefore, Bacillus sp. PSA10 was the most potential as a candidate for PHB production from sago starch on industrial scale since it was produced PHB at higher amount $(66,81 \%)$ and at a short incubation time (48 hour).

\section{Acknowledgement}

The research was supported a Fundamental research grant by Indonesian Directorate General of Higher Education, No. 097-2/PPK/Unhalu/V/2013, Ministry of Government of Indonesia.

\section{References}

Aarthy, N. and Ramana, K.V., 2011. Identification and Characterization of Polyhydroxybutyrate producing Bacillus cereus and Bacillus mycoides strains. Int. J. of Environ. Sci., 1 (5), 744-756.

Anderson, A.J. and Dawes, E.A., 1990. Occurence, Metabolism, Metabolic Role and Industrial Uses of Bacterial Polyhydroxyalkanoates. Microbiological Reviews. 54 (4) : 450-472.

Dubois, M., Gilles, K.A., Hamilton, J.K., Rebers, F.A. and F. Smith. 1956. Colorimetric Method for Determination of Sugars and Related of Substances. Analytic Chemistry, 18 (33), 350-358.

Halami, P.M., 2008. Production of polyhydroxyalkanoate from starch by the native isolate Bacillus cereus CFR06. World Journal Microbiology and Biotechnology, 24, 805-812.

Kim, B.S., 2000. Production of poly(3hydroxybutyrate) from inexpensive substrates. Enzyme and Microbial Technology, 27, 774-777. 
Lee, S.Y., 1996. Plastic Bacteria? Progress and Prospect for Polyhydroxyalkanoate Production in Bacteria. Tibtech, 14, 431438.

Madison, L.L. and Huisman, G.W., 1999. Metabolic Engineering of Poly (3-Hydroxyalkanoates) : From DNA to Plastics. Microbiology and Molecular Biology Review, 63 (1), 21-53.

Ramadas, N.V. Singh, S.K., Soccol, C.R. and Pandey, A., 2009. Polyhydroxybutyrate Production using Agro-industrial Residue as Substrate by Bacillus sphaericus NCIM 5149. Brazilian Archives of Biology and Technology, 52, 17-23.

Ramsay, B.A., Lomaliza, K., Chavarie, C., Dube, B., Bataille, P. and Ramsay, J.A., 1990. Production of Poly- $(\beta$-HydroxybutyricCo- B-Hydroxyvaleric) Acids. Applied and Environmental Microbiology, 56 (7), 2093-2098.

Syamsu, K., Fauzi, A. M., Hartoto, L., Suryani, A and Nur Atifah., 2006. Utlization of Hydrolyzed Sago Starch as Main Substrate for the Production of Bioplastic Poly Hydroxy Butyrate (PHB) By Rasltonia eutropha on Fed Batch Cultivation System. Proceedings The Fifth Regional UNINET Conference and International Seminar 2006. The 21 st Century: The Era of Bioscience Challenge and Hope. 22 -23 June 2006, Medan North Sumatra, Indonesia.

Taherzadeh, M.J. and Karimi, K., 2007. Enzyme-based Hydrolysis Processes for Ethanol form Lignocellulosic Materials : A Review. Bioresouces, 2 (4), 707-738.

Thakur, P.S., Borah, B., Baruah, S.D. and Nigam, J.N., 2001. Growth-Associated Production of Poly- $\beta$-hydroxybutyrate by Bacillus mycoides. Folia Microbiology, 46 (6), 488-494.

Yanti, N.A., Sembiring, L. and Margino, S., 2009a. Amylolytic Bacteria Producing The Raw Material of Bioplastic. Berkala Penelitian Hayati, 3C, 95-99.

Yanti, N.A., Sembiring, L. and Margino, S., 2009b. Production of Poly- $\beta$ - hydroxybutyrate (PHB) from sago starch by the native isolate Bacillus megaterium PSA10. Indonesian Journal of Biotechnology, 14 (1), 1111-1116.

Yanti, N.A., Sembiring, L. and Margino, S., 2009c. Amylolytic Bacteria Isolated from sago starch Processing Area. Proceeding in Seminar Nasional Biologi, Ilmu Lingkungan dan Pembelajaran. Universitas Negeri Yogyakarta, Yogyakarta, 4 Juli 2009.

Yuksekdag, Z.N., Aslim, B., Beyatli, Y. and Mercan, N., 2004. Effect of Carbon and Nitrogen Sources and Incubation Times on Poly-Beta-hydroxybutyrate (PHB) Synthesis by Bacillus subtilis 25 and Bacillus megaterium 12. African Journal of Biotechnology, 3 (1), 63-66. 